\title{
Assessment of an artisanal shrimp fishery of Litopenaeus vannamei in a lagoon-estuarine system based on the concept of maximum sustainable yield
}

\author{
Evaluación de una pesquería artesanal del camarón Litopenaeus vannamei en un sistema \\ lagunar-estuarino basada en el concepto de rendimiento máximo sostenible \\ Gustavo Rivera-Velázquez ${ }^{1}$, Luis A. Soto ${ }^{2}$, Isaía H. Salgado-Ugarte ${ }^{3}$ \\ and Eduardo J. Naranjo ${ }^{4}$ \\ ${ }^{1}$ Facultad de Ciencias Biológicas. Universidad de Ciencias y Artes de Chiapas. Libramiento Norte 1150. \\ Tuxtla Gutiérrez, Chiapas, México C.P.29039 \\ ${ }^{2}$ Instituto de Ciencias del Mar y Limnología, Universidad Nacional Autónoma de México, México, D. F. 04510 \\ ${ }^{3}$ Laboratorio de Biometría y Biología Pesquera, Facultad de Estudios Superiores Zaragoza, \\ Universidad Nacional Autónoma de México. Av. 5 de Mayo y Fuerte de Loreto, \\ Col. Ejército de Oriente, Iztapalapa, México, D. F. C.P. 09230 \\ ${ }^{4}$ El Colegio de la Frontera Sur. Carretera Panamericana y Periférico Sur $s / n$. \\ San Cristóbal de Las Casas, Chiapas, México C.P. 29290 \\ rivegu@hotmail.com
}

Resumen.- La aparente simplicidad del concepto del modelo de producción excedente ha motivado su uso amplio por los responsables de la ordenación de la explotación de stocks de camarón costero. Sin embargo, no se ha usado para la evaluación de poblaciones de camarón en sistemas integrados por lagunas costeras y estuarios de pesquerías cuya estructura sólo incluye embarcaciones pequeñas restringidas a las lagunas y los estuarios poco profundos. En este estudio el concepto de Rendimiento Máximo Sostenible (RMS) es usado como base para la evaluación de una pesquería de camarón (Litopenaeus vannamei) en el sistema lagunar-estuarino Carretas-Pereyra, del Golfo de Tehuantepec, México. Se aplicó un modelo dinámico de biomasa para analizar la Captura por Unidad de Esfuerzo (CPUE) de 1983-2006. En la captura comercial se identificaron dos tipos principales de métodos de pesca: esparavel (o atarraya) y encierro estacional. La máxima producción de camarón (806t) se registró en 1987, después de este año la CPUE adquirió una tendencia negativa. A partir de 1995 el esfuerzo se mantuvo constante pero el patrón de captura continuó decreciente. La producción total observada desde el 2000 se encuentra por debajo (58\% promedio) del RMS estimado, $248.393 \mathrm{~kg}$ año ${ }^{-1}$. El Esfuerzo Observado (505 embarcaciones) superó en un $45 \%$ al Esfuerzo Estimado en el RMS ( $\mathrm{E}_{\mathrm{RMS}}=349$ embarcaciones). Los resultados sugieren condiciones de sobreexplotación del stock de camarón, un patrón de decremento en la abundancia y un serio riesgo de colapso económico de la pesquería en el área de estudio.

Palabras clave: Laguna costera, estuario, CPUE, sobreexplotación

\begin{abstract}
The apparent simplicity of the concept of the surplus production model has promoted its wide application among fishery managers responsible for the exploitation of offshore shrimp stocks. However, no attempts have been made to utilize it for the assessment of shrimp populations exploited in coastal lagoons-estuarine systems. These are artisanal fisheries whose structure includes small boats and fixed fishing traps. In this study the concept of maximum sustainable yield was used (MSY) as a base for the evaluation of the shrimp fishery (Litopenaeus vannamei) in the lagoon-estuarine system Carretas-Pereyra, Gulf of Tehuantepec, Mexico. A dynamic biomass model was applied to analyze catch per unit effort (CPUE) of 1983-2006. In the commercial exploitation of the shrimp stock two main types of fishing methods are employed: stationary enclosures and cast nets. Maximum shrimp production (806 t) was recorded in 1987, followed by a sustained declining trend of CPUE thereafter. Even though fishing effort remained constant since 1995, the shrimp landings maintained a declining trend. Total shrimp production recorded from 2000 fell below the estimated level (mean $=58 \%$ ) of maximum sustainable yield (MSY) at 248,393 $\mathrm{kg} \mathrm{yr}^{-1}$. Observed effort (505 fishing vessels) was $45 \%$ over the estimated effort at $\mathrm{MSY}\left(\mathrm{E}_{\mathrm{MSY}}=349\right.$ vessels $)$. These results reveal conditions of overexploitation of the shrimp stock, a declining pattern in its abundance, and a serious risk of an economic collapse of the shrimp fishery in the study area.
\end{abstract}

Key words: Coastal lagoon, estuary, CPUE, overexploitation 


\section{Introduction}

Coastal lagoons and estuaries are fairly recent geological features (less than 5000 years old) and common ecosystems with complex structure and dynamics that preserve communities of high biotic diversity (Day et al. 1989). Within these communities different penaeid shrimp species play a major ecological function. They are consumers of organic matter provided by a rich substratum in aquatic vegetation and mangroves (Hendrickx 1995). They are also important preys for predator birds, fish and crustaceans (Menz 1976) thus contributing to maintain the dynamics of the ecosystem, and sustaining tropical artisanal fisheries (GamboaContreras \& Tapia-García 1998).

Coastal penaeid shrimp inhabit intertropical and subtropical waters. A feature of many shrimp species is an amphibiotic cycle including a coastal or estuarine juvenile stage, and an adult stage in offshore waters. This peculiarity has allowed penaeid shrimp stocks to support different types of fisheries: (1) Artisanal, present in many countries due to its minimum investment requirements and its large socio-economic benefits (García \& Le Reste 1981). In this case, the catch is usually composed by both small juveniles and subadults emigrating to the sea; (2) The industrial fishery operates mostly in the offshore waters and has had a dramatic increase in production since the middle of the $20^{\text {th }}$ century due to the use of more sophisticated and efficient fishing methods (García \& Le Reste 1981); and (3) Postlarvae extraction, an increasing practice since the 1970's to supply the demand of commercial shrimp farms (Andrade 1992, Parra 1992, Cabrera \& Soto 2008).

In an attempt to implement a fishing management program, the initial assessment of the CPUE is a most valuable analytical tool, particularly when surplus production models are being applied (Morales-Bojórquez et al. 2001). These models allow the estimation of fishing effort levels at which a Maximum Sustainable Yield (MSY) can be attained without long-term negative effects on stock productivity (Sparre \& Venema 1997). The use of the biomass dynamic model in fisheries management is based on the assumption that Maximum Surplus Production (MSP) is reached when population biomass is at $50 \%$ of its natural carrying capacity $(\mathrm{K})$, and if this level remains constant, then it is possible to attain MSY. To keep the population biomass at MSY, it is required to consider fishing mortality (F). Theoretically in a fishery, MSY is obtained when F equal natural mortality (M), assuming that maximum potential yield is at $0.5 \mathrm{~K}$ (Csirke 1989).

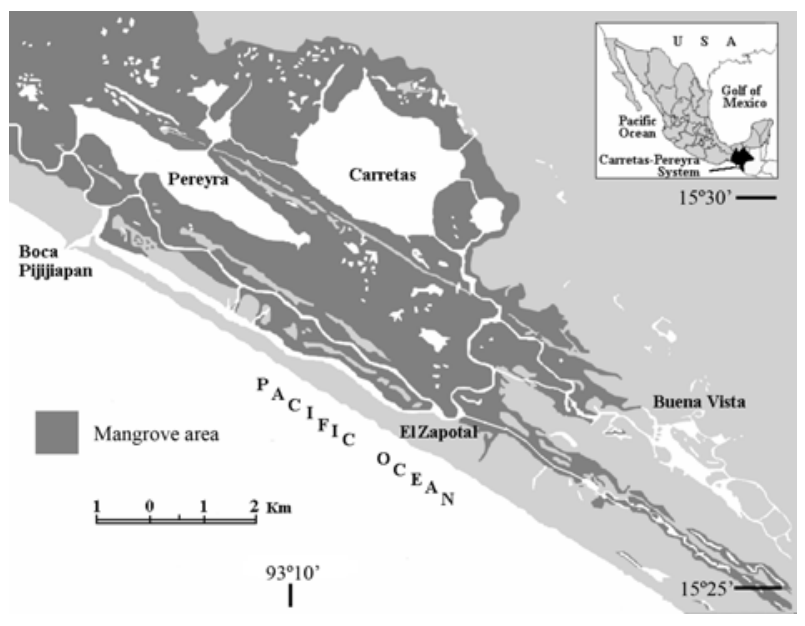

Figure 1

Location of Carretas-Pereyra lagoon-estuarine system, La Encrucijada Biosphere Reserve, Chiapas, Mexico (Rivera-Velázquez et al. 2008)

Localización del sistema lagunar-estuarino Carretas-Pereyra, Reserva de Biosfera La Encrucijada, Chiapas, México (Rivera-Velázquez et al. 2008)

Unfortunately, current knowledge on the shrimp fishery in the Carretas-Pereyra system is still limited, particularly on the annual CPUE trends and the efficiency of existing management practices that involve: closing seasons in offshore waters, effort restrictions, and fishing gear regulations. The lack of accurate fishing effort records in the area of study has prompted the experts to assume that the fishing effort is a constant parameter in the analyses (García-Borbón et al. 2004). This lagoonestuarine system, in the south Pacific of Mexico (Fig. 1), sustains an artisanal shrimp fishery whose appropriate exploitation and management are urgent. This paper presents an analysis of CPUE and effort trend in the Carretas-Pereyra system shrimp fishery in the past two decades, as well as an assessment of the maximum sustainable yield (MSY) and effort at MSY $\left(\mathrm{E}_{\mathrm{MSY}}\right)$. Based on the information derived from the MSY analysis the current fishing practices in the area of study are discussed emphasizing the fragile biological and economical condition of the artisanal shrimp fishery due to insufficient data that preclude the implementation of sound policy decisions. 


\section{Material and methods}

A production database of the five fishing cooperative groups operating in the Carretas-Pereyras system from 1983 through 2006 was created. The official fishery statistics were further reinforced with local fishermen's records. This database included total catch (tons), number of fishermen, boats, and type of fishing method employed. Prior to the selection of the best fishing effort unit, the different capture devices were reviewed in the estuarine system. Cast nets and stationary wooden enclosures represented the main capture devices used by the artisanal shrimp fishery. The cast net is a fishing gear ('atarraya') 6 to $7 \mathrm{~m}$ in diameter and a size mesh of $1.8-2.5 \mathrm{~cm}$ regularly employed by local fishermen (Fig. 2). The stationary wooden enclosures ('tapo') are capturing devices deployed in shallow waters of the estuarine system (Fig. 3), consisting of a line of stakes closely aligned across shallow channels; the stakes serve as supporting structures for nets of $1.8 \mathrm{~cm}$ mesh size that retain juvenile shrimps in their seaward emigration (Edwards 1977, García \& Le Reste 1981). Unfortunately, the information obtained about the number of fishermen and capture methods was incomplete for some years within the period studied. In order to fill up the gap of missing data, it was assumed that the last existing records remained constant. The catch observed for stationary enclosures was maintained constant at 50 fishermen (10 fishermen per fishing group). To describe the fishing method, determining the costs of fishing devices and estimating the production of stationary wooden enclosures, nearly $30 \%$ of all fishermen in the system were interviewed to update production records. In order to perform independent analyses of each fishing method, data were gathered in two ways: Firstly, the shrimp production corresponding to stationary enclosures reported in books of fishermen associations was obtained. Available information for stationary enclosures corresponded to the period 2001-2006, and the average capture of these years represents $38 \%$ of total production. Secondly, the interviews with fishermen verified that the production of stationary enclosures contributes with 30$40 \%$ of the total. Therefore, it was considered appropriate to carry out the evaluation of the fishery considering $38 \%$ as a representative proportion of the capture obtained in stationary enclosures for the period of study (1983-2006).

Catch per unit effort (CPUE) was calculated dividing catch records by their respective effort. This variable was analyzed using Hilborn \& Walters (1992) dynamic biomass model assuming non-equilibrium conditions:

$$
B_{t+1}=B_{t}+r B_{t}\left(1-\frac{B_{t}}{B o}\right)-C_{t}
$$

where $t$ represents time (fishing season), $B_{t}$ is population biomass at time $t, r$ is the intrinsic rate of population increase, $B o$ is biomass at carrying capacity, and $C_{t}$ represents catch obtained either by cast nets or stationary enclosures at time $t$.

Biomass at carrying capacity ( $B o$ ) was estimated assuming that catch rate is proportional to stock size using the relationship $B_{1}=C_{l} /\left(E_{l} q\right), B_{1}$ is population biomass at time $1, C_{1}$ represents catch at time $1, E_{1}$ represents effort at time 1, and $q$ is catchability coefficient (Hilborn $\&$ Walters 1992). Since the recorded $C$ was highly variable during the first five years, a mean value was calculated for that period. Intrinsic rate of natural growth ( $r$ ) was derived from Blueweiss et al. model (1978 vide in Pauly 1983):

$$
r=0.025 W^{-0.26}
$$

where $W=$ weight. The catchability coefficient $(q)$ was calculated using Leslie and Davis's model (1939 vide in Krebs 1997):

$$
q=\frac{-\sum_{i=1}^{s} Y\left(K_{i}-\bar{K}\right)}{\sum_{i=1}^{s}\left(K_{i}-\bar{K}\right)^{2}}
$$

where $q=$ catchability, $Y=$ catch per unit effort, $\bar{K}=$ mean accumulated catch, and $s=$ sample size.

Maximum sustainable yield (MSY) and Effort at MSY $\left(\mathrm{E}_{\mathrm{MSY}}\right)$ were assessed with Hilborn \& Walters (1992) dynamic biomass model estimator. Maximum potential yield (MPY) was also estimated using the relationship MPY $=0.5$ MBo (Csirke 1989), where $M=$ natural mortality, and $B o=$ biomass at carrying capacity. $M$ was fixed at 0.25 derived from a previous study (RiveraVelázquez et al. 2008).

For MSY and $\mathrm{E}_{\mathrm{MSY}}$ estimations corresponding to cast nets, long-term data on annual yields was used to allow a better adjustment of parameters ' $a$ ' and ' $b$ ' (Big Numbers Law vide in Grinstead \& Snell 1997). These data were also useful to minimize impact of potential shifts in recruitment or environmental variations affecting either abundance or distribution of the resource.

Fishing effort at maximum economic yield $\left(\mathrm{E}_{\mathrm{MEY}}\right)$ was assessed through Gordon-Schaefer's Bioeconomic model (vide in Seijo et al. 2005). This model states that net revenue (NR) from fishing is a function of total revenue (TR) and total cost (TC): NI=TSI-TC. To maximize revenues for society, it is necessary that fisheries operate within a certain level of $\mathrm{E}_{\mathrm{MEY}}$. This criterion was obtained 


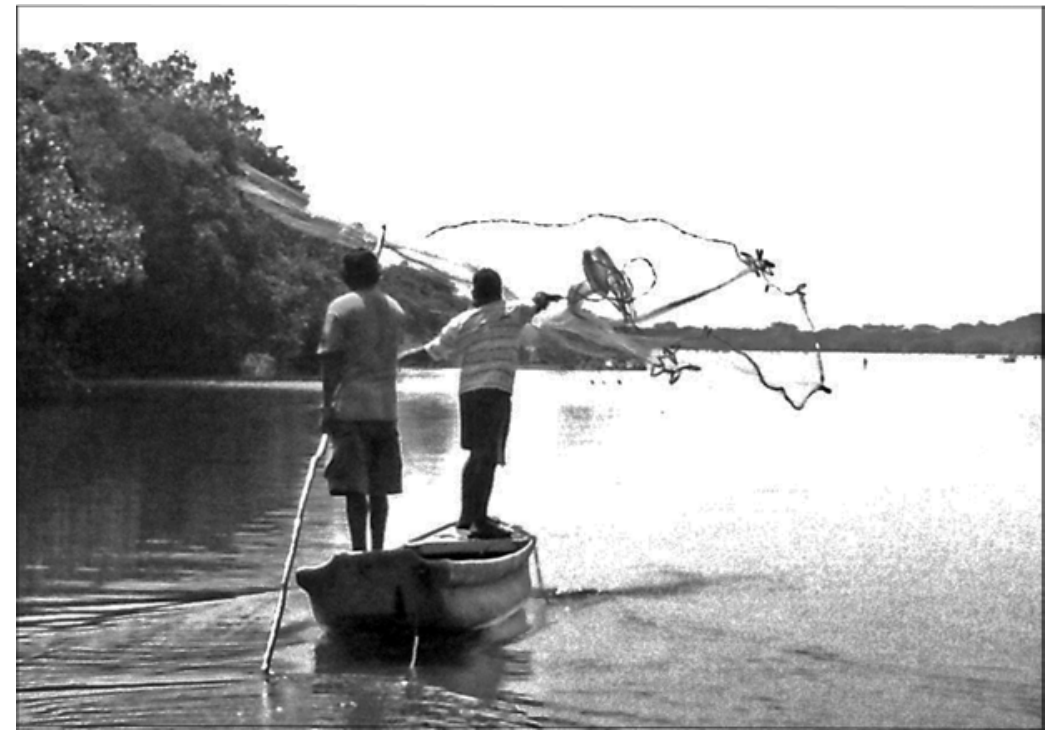

Figure 2

Operation of cast nets in the penaeid shrimp fishery of Carretas-Pereyra lagoon-estuarine system, Gulf of Tehuantepec, Mexico

Empleo de redes 'atarraya' en la pesquería de camarones peneidos en el sistema lagunarestuarino, Carretas-Pereyra, Golfo de Tehuantepec, México

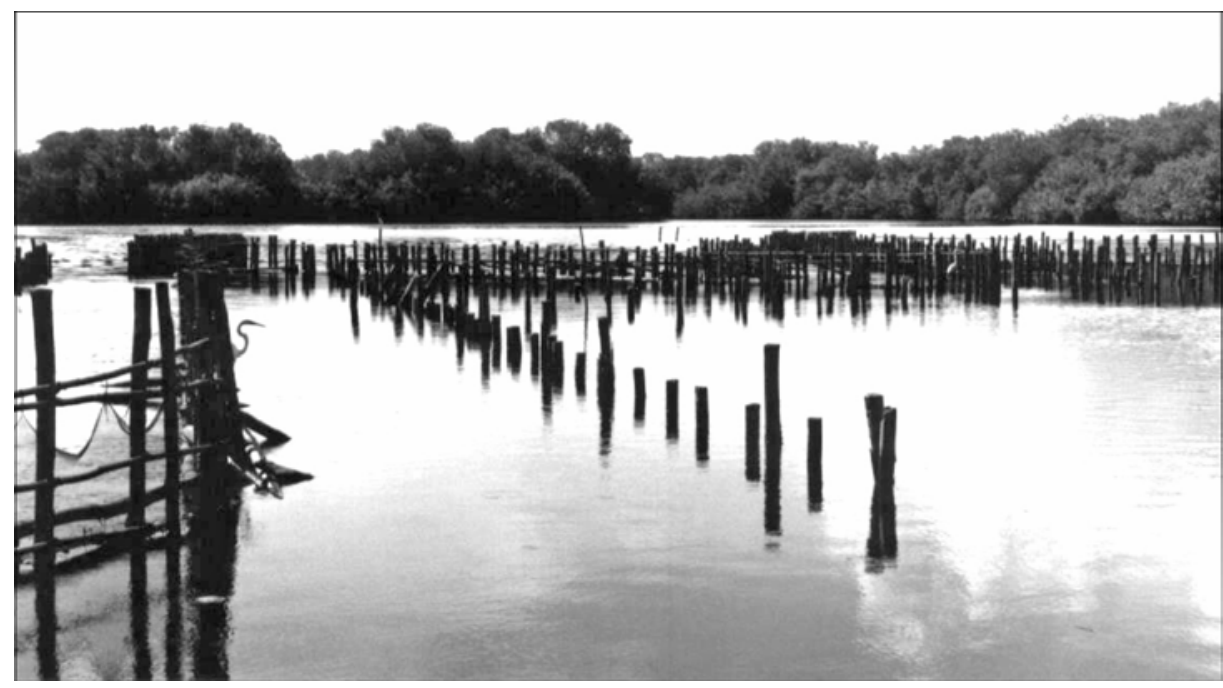

Figure 3

Stationary wooden enclosure 'tapo' deployed across shallow channels employed by shrimps in their seaward emigration in the Carretas-Pereyra lagoon-estuarine system, Gulf of Tehuantepec, México

Encierro estacionario rustico 'tapo' construido transversalmente en un canal somero el cual emplean los camarones peneidos para emigrar al mar, en el sistema lagunar-estuarino Carretas-Pereyra,

Golfo de Tehuantepec, México 
by maximizing differences between TSI and TC of fishing effort:

$$
\mathrm{TR}=\operatorname{pr} B\left(1-\frac{B}{B o}\right) \text { and } \mathrm{TC}=\left(\frac{c r(1-(B / B o))}{q}\right)
$$

where $\mathrm{TR}=$ total revenue, $p=$ price of shrimp, $r=$ Intrinsic rate of natural growth, $B=$ biomass, $B o=$ carrying capacity, $\mathrm{TC}=$ total cost, $c=$ unitary cost, $q=$ catchability coefficient.

\section{Results}

\section{Artisanal fishery operation}

In the shrimp fishery of the Carretas-Pereyra system there are 505 fiberglass boats 6 to $8 \mathrm{~m}$ of length, operating in the area. The main fishing method is the cast net. A basic fishing unit in the system is composed of two fishermen, a cast net, and a boat occasionally fitted with an outboard motor. As pointed out earlier, official records on the number and type of boats, and fishing gear were incomplete for the studied system (Table 1). The fishing census indicated that $94 \%$ of the fishermen have cast nets, $83 \%$ are boat owners and only $13 \%$ possess outboard motors. During the shrimp fishing season, fishermen usually work from 6 to 10 AM Monday through Saturday.

In the studied system there were two main stationary enclosures placed at the most productive shrimping areas of the lagoon-estuarine system (Rivera-Velázquez et al. 2008): El Zapotal and Buena Vista. They usually are constructed using red mangrove (Rhizophora mangle). They are deployed from October to November in the Carretas lagoon and in June a similar enclosure is located in the channel close to Buena Vista lagoon. These fixedfishing devices include shrimp traps placed along the migratory channels used by juvenile shrimp to exit the system during full and new moon periods from December to May. In the rest of the system, shrimp are captured with cast nets from December to August and in the Buena Vista lagoon only from July to August.

\section{Catch and fishing effort trends}

Massive shrimp emigration in the lagoon system initiates in synchrony with either full or new moon periods in late November or early December. A fishing regulation of a minimum size (100 mm total length, TL) is established by the local fishermen operating in both stationary enclosures or from boats fitted with cast nets. The exploitation of the shrimp stock it reaches a maximum of catch from February to March and declines towards June. The capture of juvenile shrimp with cast nets extends for a longer period from December to August
Table 1

\section{Fishing effort applied to $L$. vannamei in the Carretas- Pereyra lagoon-estuarine system, Chiapas, Mexico (1983-2006)}

Datos de esfuerzo para L. vannamei en el sistema lagunarestuarino Carretas-Pereyra, Chiapas, México (1983-2006)

\begin{tabular}{ccccc}
\hline Year & $\begin{array}{c}\text { Registered } \\
\text { fishermen }\end{array}$ & Boats & Cast nets & $\begin{array}{c}\text { Outboard } \\
\text { engines }\end{array}$ \\
\hline 1983 & 609 & & & \\
1984 & 610 & & & \\
1985 & 658 & & & \\
1986 & 692 & & & \\
1987 & 688 & & & \\
1988 & 741 & 341 & & \\
1989 & 903 & 376 & 914 & 21 \\
1990 & 913 & & & \\
1991 & 911 & & & \\
1992 & 964 & 391 & 715 & 9 \\
1993 & 1012 & & & \\
1994 & 1146 & 429 & 1186 & 21 \\
1995 & 1083 & 501 & 796 & 46 \\
1996 & 1004 & 501 & 797 & 45 \\
1997 & 982 & 501 & 797 & 45 \\
1998 & 1086 & 501 & 797 & 45 \\
1999 & 1086 & & 1008 & \\
2000 & 1086 & & & \\
2001 & 1086 & & & \\
2002 & 1086 & 501 & & \\
2003 & 1086 & 505 & 893 & \\
2004 & 1086 & & & \\
2005 & 1086 & & & \\
2006 & 1086 & 505 & 797 & \\
\hline
\end{tabular}

while that practiced at stationary enclosures is shorter from December to March.

\section{Catch trends}

Shrimp catch during the 1983-2006 period exhibited nearly decadal fluctuations (Table 2). In the eighties, for instance, total catch variation was the most significant ever recorded (Fig. 4). The 1987 catch was 596\% higher than that recorded in 1983. However, such an impressive trend was then followed by a sharp decline down to $204 \%$ in 1990. In the nineties, the catch average was 357 metric tons or $208 \%$ of the maximum production obtained in 1983. In the current decade, production continues its declining trend reaching just 50 metric tons obtained in 2006, representing 43\% of the shrimp production of 1983 .

The official fishing records for shrimp from the Carretas-Pereyra system include the production obtained 
Table 2

Catch and effort data for L. vannamei in the Carretas-Pereyra lagoon-estuarine system, Chiapas, Mexico (1983-2006)

Datos de captura y esfuerzo para L. vannamei del sistema lagunar-estuarino Carretas-Pereyra, Chiapas, México (1983-2006)

\begin{tabular}{|c|c|c|c|c|c|c|c|c|}
\hline $\begin{array}{l}\text { Fishing } \\
\text { season }\end{array}$ & $\begin{array}{l}\text { Total catch } \\
\quad(\mathrm{kg})\end{array}$ & $\begin{array}{c}\text { Catch } \\
\text { cast nets }\end{array}$ & $\begin{array}{c}\text { Catch } \\
\text { enclosure }\end{array}$ & \multicolumn{2}{|c|}{$\begin{array}{c}\text { Effort } \\
\text { (boats) }\end{array}$} & $\begin{array}{c}\text { Effort } \\
\text { enclosures }\end{array}$ & $\begin{array}{c}\text { CPUE } \\
\text { cast nets }\end{array}$ & $\begin{array}{c}\text { CPUE } \\
\text { enclosures }\end{array}$ \\
\hline 1983 & 115,769 & 71,777 & 43,992 & 341 & $*$ & 50 & 210 & 3147.1 \\
\hline 1984 & 321,938 & 199,602 & 122,336 & 341 & $*$ & 50 & 585 & 2466.2 \\
\hline 1985 & 495,154 & 306,995 & 188,159 & 341 & $*$ & 50 & 900 & 2524.0 \\
\hline 1986 & 513,019 & 318,072 & 194,947 & 341 & $*$ & 50 & 933 & 2531.8 \\
\hline 1987 & 806,081 & 499,770 & 306,311 & 341 & $*$ & 50 & 1,466 & 2532.6 \\
\hline 1988 & 488,788 & 303,049 & 185,739 & 341 & & 50 & 889 & 2532.7 \\
\hline 1989 & 650,292 & 403,181 & 247,111 & 376 & & 50 & 1,072 & 2792.7 \\
\hline 1990 & 352,181 & 218,352 & 133,829 & 391 & $*$ & 50 & 558 & 2810.7 \\
\hline 1991 & 294,332 & 182,486 & 111,846 & 391 & $*$ & 50 & 467 & 2762.1 \\
\hline 1992 & 399,593 & 247,748 & 151,845 & 391 & & 50 & 634 & 2755.6 \\
\hline 1993 & 361,030 & 223,839 & 137,191 & 429 & $*$ & 50 & 522 & 3022.3 \\
\hline 1994 & 277,187 & 171,856 & 105,331 & 429 & & 50 & 401 & 2916.6 \\
\hline 1995 & 273,455 & 169,542 & 103,913 & 501 & & 50 & 338 & 3387.7 \\
\hline 1996 & 367,192 & 227,659 & 139,533 & 501 & & 50 & 454 & 3160.1 \\
\hline 1997 & 492,932 & 305,618 & 187,314 & 501 & & 50 & 610 & 3120.2 \\
\hline 1998 & 124,665 & 77,292 & 47,373 & 501 & & 50 & 154 & 3110.7 \\
\hline 1999 & 622,092 & 385,697 & 236,395 & 501 & $*$ & 50 & 770 & 3108.3 \\
\hline 2000 & 211,631 & 131,211 & 80,420 & 501 & $*$ & 50 & 262 & 3107.7 \\
\hline 2001 & 195,738 & 121,358 & 74,380 & 501 & $*$ & 50 & 242 & 3107.5 \\
\hline 2002 & 190,258 & 117,960 & 72,298 & 501 & $*$ & 50 & 235 & 3107.5 \\
\hline 2003 & 151,452 & 93,900 & 57,552 & 505 & & 50 & 186 & 3132.3 \\
\hline 2004 & 103,000 & 63,860 & 39,140 & 505 & $*$ & 50 & 126 & 3120.7 \\
\hline 2005 & 112,000 & 69,440 & 42,560 & 505 & $*$ & 50 & 138 & 3117.8 \\
\hline 2006 & 50,000 & 31,000 & 19,000 & 505 & & 50 & 61 & 3117.1 \\
\hline
\end{tabular}

* Estimated value based on the last available record. The production unit this integrated by boat, cast nets (atarraya) and two fishermen

Table 3

L. vannamei catch in enclosures vs. total catch in the Carretas-Pereyra lagoon-estuarine system, Chiapas, Mexico (seasons 2001-2006)

Captura de L. vannamei en el encierro estacional vs. captura total en el sistema lagunar-estuarino Carretas-Pereyra, Chiapas, México (temporadas 2001-2006)

\begin{tabular}{ccccc}
\hline $\begin{array}{c}\text { Season } \\
\text { (November-July) }\end{array}$ & $\begin{array}{c}\text { Total catch } \\
\text { (metric tons) }\end{array}$ & $\begin{array}{c}\text { Catch in } \\
\text { El Zapotal } \\
\text { enclosure }\end{array}$ & $\begin{array}{c}\text { Catch in enclosures } \\
\text { extrapolated to five } \\
\text { cooperative groups }\end{array}$ & \% of total catch \\
\hline $2000-2001$ & 195.738 & $11.553 *$ & 57.765 & 30 \\
$2001-2002$ & 190.258 & $11.000 *$ & 55.000 & 29 \\
$2002-2003$ & 151.452 & $13.390 *$ & 66.950 & 74 \\
$2003-2004$ & 103.000 & $15.374 * *$ & 76.870 & 13 \\
$2004-2005$ & 112.000 & $3.000 * *$ & 15.000 & 40 \\
$2005-2006$ & 50.000 & $4.016 * *$ & 20.080 & \\
\hline
\end{tabular}

* Obtained from the landing records of Obreros del Mar Cooperative Society

** Obtained from official landing records of Brisas de Pijijiapan Cooperative Society 


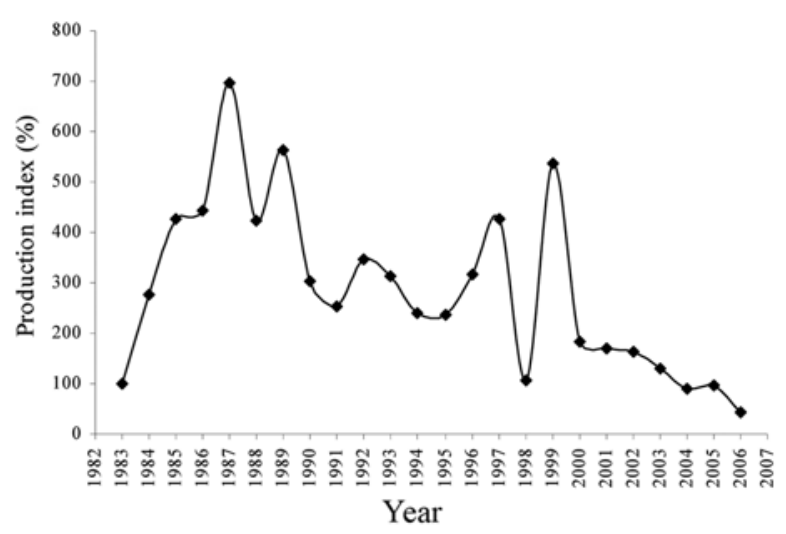

Figure 4

\section{Production index, based on annual total catch of L. vannamei}

Índice de producción en el tiempo, con base en las capturas totales anuales de L. vannamei

from both enclosures and cast nets. Consequently, production data from each enclosure are either unavailable or incomplete. Nevertheless, based one fishermen interview it was estimated that the production in the traps of the stationary enclosures constitutes amounts 30 or $40 \%$ of total shrimp production. With the obtained data it is observed that the volume taken place in the confinement the period 2001-2006 varies from 15 to 78 tons that represent from 13 to $75 \%$ of total capture (Table 3). To estimate the MSY and $\mathrm{E}_{\mathrm{MSY}}$ supposed that the average (38\%) it is the behavior in the whole period (1983-2006).

\section{Effort trends}

The number of fishing boats in the Carretas-Pereyra system was the variable applied in the analysis of the annual shrimp production (Fig. 5). Between 1983 and 1995, the number of boats increased from 341 to 501 (> 47\%). More recently, from 2003 to 2006, official records showed a negligible increase ( 505 boats). The maximum fishing efforts were recorded in 1989 (10\% above the previous year), 1993 (10\%), and 1995 (17\%) (Fig. 5). No decrease in fishing effort was detected in the available historical records, and it has remained mostly constant causing declining yields since 1995. Interestingly enough, the field survey revealed that the social behavior of fishing cooperatives mirrors that of migratory workers that temporarily abandon their traditional activities in search for better sources of income. Nearly $45 \%$ of the fishermen are involved in another activity and only $20 \%$ remain active throughout the shrimp season. In spite of this local phenomenon, no clear changes in fishing effort were noted.

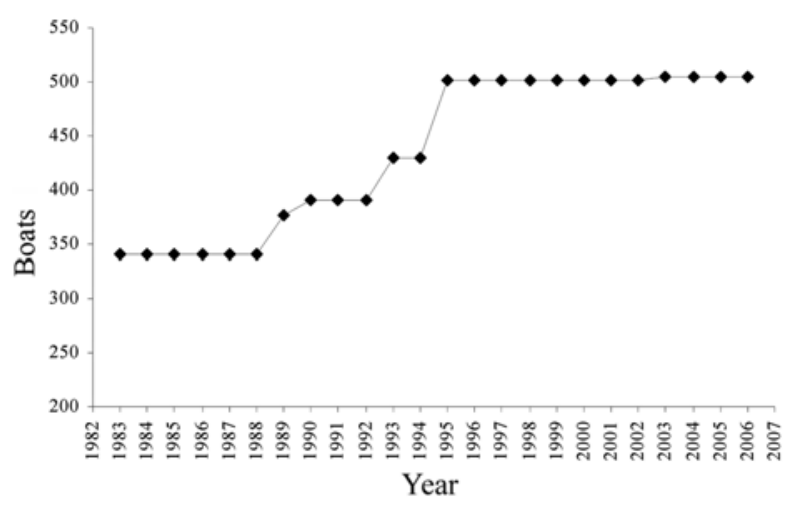

Figure 5

Number of boats used in the L. vannamei fishery of Carretas-Pereyra lagoon estuarine system, Chiapas, Mexico (1983-2006)

Número de embarcaciones usadas en la pesquería de $L$. vannamei del sistema lagunar-estuarino Carretas-Pereyra, Chiapas, México (1983-2006)

\section{Analysis of catch $v s$. effort}

The CPUE trend in the Carretas-Pereyra system for the period 1983-2006 is shown in Fig. 6. Maximum production was recorded in 1987, when effort remained constant. Later a noticeable increment in fishing effort occurred in 1989, 1993 and 1995. Between 1987 and 2006, CPUE fell down from $1,466 \mathrm{~kg}$ boat $^{-1}$ to only 61 $\mathrm{kg}$ boat $^{-1}$ (Table 2). This is interesting considering that after 1987, CPUE showed a sustained a declining trend, which is a common feature in an over-exploited fishery. In 1997 and 1999, the CPUE was relatively high. However, the declining trend occurred again after those years and continued until 2006. In 1989, 1993, and 1995, there were noticeable increments in effort, but no corresponding increments in CPUE or in production were recorded. It is worth noting a couple of similar peaks in the historic record of the CPUE, occurring in 1987-1989, and in 1997-1999 (Fig. 6).

\section{El Niño effect}

The El Niño phenomenon was present every year between 1991 and 1995 in the study area, but it occurred on an irregular basis (every 2, 3 or 4 years) within the whole period of analysis (1983-2006, Magaña et al. 2006', Fig. 7). In

\footnotetext{
${ }^{1}$ Magaña RV, JL Pérez, C Conde, C Gay \& S Medina. 2006. El fenómeno de El Niño y la Oscilación del Sur (ENOS) y sus impactos en México. Departamento de Meteorología General, Centro de Ciencias de la Atmósfera, UNAM. [on-line] < http:/ /www.atmosfera.unam.mx/cclimatico/doc_pdf/nino.pdf >
} 


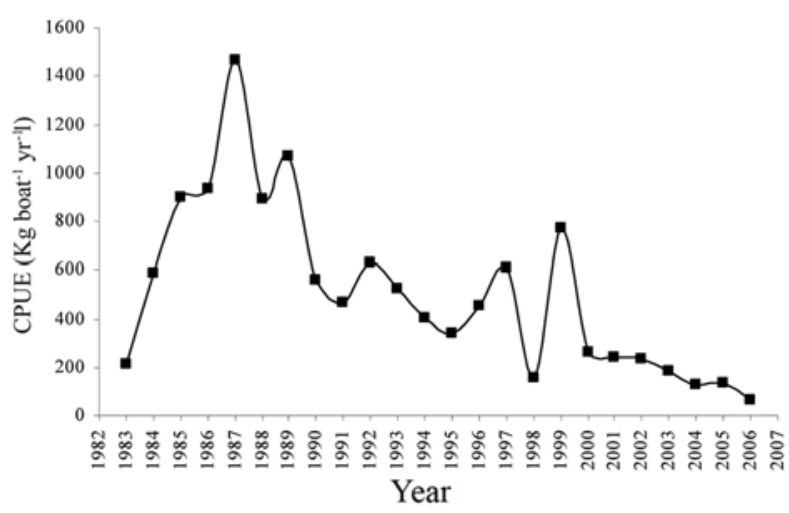

Figure 6

Catch per unit effort (CPUE) of $L$. vannamei fishing in the Carretas-Pereyra lagoon-estuarine system, Chiapas, Mexico (1983-2006)

Captura por unidad de esfuerzo (CPUE) de la pesquería de L. vannamei del sistema lagunar-estuarino Carretas-Pereyra, Chiapas, México (1983-2006)

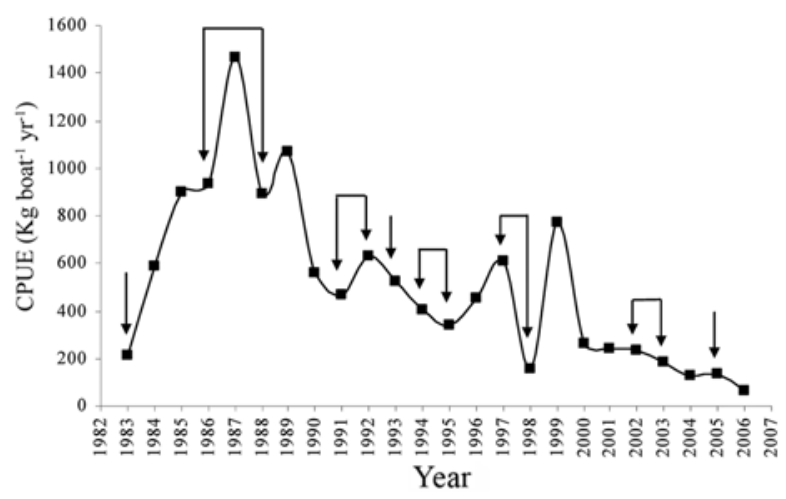

Figure 7

Trend of $L$. vannamei catch per unit effort (CPUE) and occurrence of El Niño phenomenon (represented by arrows; Werner 2006) in the Carretas-Pereyra lagoon-estuarine system, Chiapas, Mexico (1983-2006)

Tendencia de la captura por unidad de esfuerzo (CPUE) de L. vannamei y ocurrencia del fenómeno El Niño (representado por las flechas; Werner 2006) en el sistema lagunar-estuarino Carretas-Pereyra, Chiapas, México (1983-2006)
post-El Niño years, the CPUE increased with respect to the previous year (e.g. 1984, 1989, 1996, and 1999). Exceptions to this trend were 2004 and 2006, but both years corresponded to the decade when there were no significant oscillations in production.

$\mathrm{MSY}, \mathrm{E}_{\mathrm{MSY}}, \mathrm{MPY}$, and $\mathrm{E}_{\mathrm{MEY}}$

Catch and effort of shrimp fishing with cast nets indicate a continuous increment in yield until a maximum was reached at 341 boats. With an effort higher or lower than this, yields were always kept low (Fig. 8; Table 2). The estimator applied suggests that shrimp biomass was originally large (Fig. 9), but it declined as catch augmented. After that, catch progressively decreased but the stock did not recover. MSY calculated with Schaefer's model (1954) was 290,813 $\mathrm{kg} \mathrm{yr}^{-1}$, and $\mathrm{E}_{\mathrm{MSY}}$ was equivalent to 294 boats. The MSY estimated through Hilborn \& Walters model (1992) was 248,393 kg year-1, and $\mathrm{E}_{\mathrm{MSY}}$ was 349 boats. MPY was estimated at 179,582 $\mathrm{kg}$ of shrimp per fishing season, and $\mathrm{E}_{\mathrm{MEY}}$ was 225 boats per season. The total annual cost, per basic fishing unit when the study (boat and cast net), was valued at $\$ 1,420$ US. Because over $85 \%$ of boats use the same gears and fishing strategies (in teams), it was assumed that the fleet is basically homogeneous.

\section{Discussion}

Selecting the measurement that best represents a fishing effort unit (fishermen numbers, boats, trips, and time) is in itself a complex problem because of the variability of this activity (García \& Le Reste 1981). Fishing and CPUE depend on fleet and resource character, as well as on local environmental conditions (González-Becerril et al. 2000). The assessment of capture techniques employed in the Carretas-Pereyra fishery allowed the recognition of two primary fishing methods with clear differences in operation efficiency, species selectivity and yield. Firstly, as earlier indicated, a boat operated by two fishermen and a cast net constitutes the basic fishing unit in the system. Secondly, the stationary enclosures are run by a working force of 50 fishermen. It is important to recognize that there are no differences in the price of the product obtained by the two fishing methods.

Shrimp catch obtained with cast nets implies a significant effort that produces relatively low yield per fishing unit. However, this fishing strategy provides employment and generates most of the system production (ca. 68\%) and income. The stationary enclosure has apparently important advantages over the cast net: its operation requires less effort, its yields are higher, and it is more selective. However, one major disadvantage is its high building cost (e.g. US \$57,091 in 2006), and a 


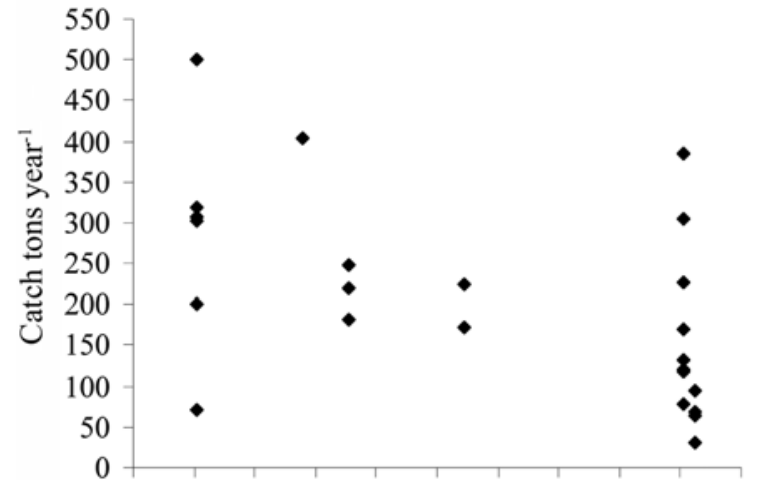

$320340360380400420440460 \quad 480500 \quad 520$

Boats standard/year (1983-2006)

Figure 8

Trend of $L$. vannamei catch vs. unit effort in the Carretas-Pereyra lagoon-estuarine system, Chiapas, Mexico (1983-2006)

Tendencia de la captura $v$ s. unidad de esfuerzo de L. vannamei en el sistema lagunar-estuarino Carretas-Pereyra, Chiapas, México (1983-2006)

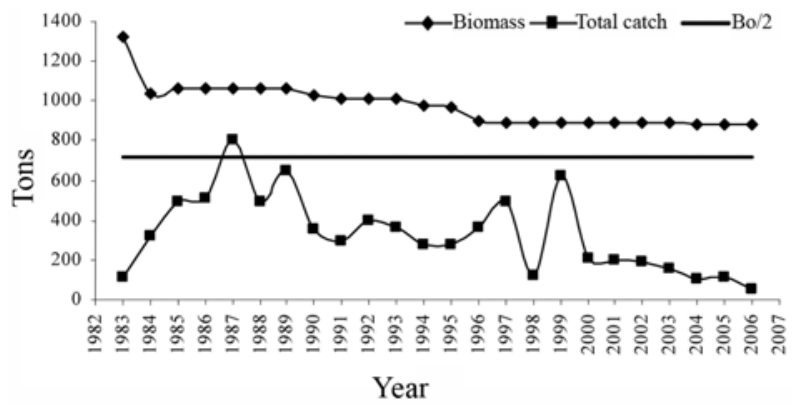

Figure 9

Shrimp biomass assessment through Schaefer's dynamic model (Hilborn \& Walters 1992), Virgin biomass at $0.5(\mathrm{Bo} / 2)$, total biomass observed and total catch. Lagoon-estuarine system Carretas-Pereyra, Chiapas, Mexico (1983-2006)

Biomasa de camarón calculada con el estimador de Schaefer (Hilborn \& Walters 1992), Biomasa virgen al 0,5 $(\mathrm{Bo} / 2)$, biomasa observada y captura total. Sistema lagunar-estuarino Carretas-Pereyra, Chiapas, México (1983-2006) limited number of employment opportunities for local fishermen.

A close look at the significant shrimp production attained from 1983 through 1987 revealed the combined effect of several factors. On one hand, probably the number and the field experience of fishermen in this period have gradually increased in numbers and experience. On the other hand, boats and fishing gear were refurbished (Toledo 1994, IDESMAC 1998) ${ }^{2}$. Guerra \& Sánchez (1998) have pointed out that these new conditions promoted a higher fishing effort. Further analysis of the available records showed a discrepancy between the official records and field census. According to official information (nominal effort) for boats and cast nets, only $47 \%$ of the artisanal shrimp fleet operates with modern fishing gear, when in reality (real effort) nearly $83 \%$ of the fleet has fiber-glass boats and efficient cast nets made with nylon mesh. Deficiencies in record keeping have been a common problem in artisanal fisheries (Morales-Bojórquez et al. 2001), and this lack of reliable information seriously precludes any attempt to conduct an adequate assessment of marine and freshwater biotic resources (Arena \& Rey 2003).

Shrimp catch decreased (with oscillations) from 1987 through 2000. There is a clear inverse trend in effort in this period, particularly between 1988 and 1995, when both fishermen and boat numbers augmented without control of fishing mortality. Under these circumstances, the fishery could have surpassed MSY (even though effort appears stable after 1995), causing a sharp decline in the annual catch of subsequent years, to the point that production from 2000 on wards has maintained a negative tendency at the lowest volumes ever recorded.

The Carretas-Pereyra artisanal shrimp fishery had an open-access regime until 1994 (Seijo et al. 2005). From 1995 on fishing authorities issued concessions of exploitation rights to the five fishermen associations previously operating in the system, shifting to a commonproperty regime (Seijo et al. 2005). During the openaccess regime, effort continuously increased (47\% between 1983 and 1995; Table 2). With the commonproperty regime, official records show a constant effort in spite of evidence suggesting an increase in boat numbers. In addition, there are non-registered members within the five fishing associations, whose catch landings

${ }^{2}$ IDESMAC. 1998. Manejo y conservación de cuencas compartidas entre las reservas de la biosfera 'El Triunfo' y 'La Encrucijada', Chiapas, México. Estudio socioeconómico en la cuenca hidrológica de Pijijiapan, Chiapas, Tomos I y II, 280 pp. Informe Técnico del Instituto para el Desarrollo Sustentable en Mesoamérica AC, San Cristóbal Las Casas. 
go unrecorded. Due to this abnormal situation, one may assume that the fishery actually continues operating under an open-access regime.

In tropical fisheries management, biomass dynamic models are widely applied because their historical catch composition is usually not available or is not reliable (Morales-Bojórquez et al. 2001), as in the case of the Carretas-Pereyra fishery. In spite of shrimp catch statistic records including boats (with their respective cast nets) and stationary enclosures with no distinction, an attempt was made to estimate the catch obtained from these two sources. The CPUE was assessed using effort data from boats (and cast nets), but this was not possible for stationary enclosures due to lack of information, although their catch constitutes a considerable portion of the total shrimp production in the system. This problem emphasizes the need to promote monitoring of catch and effort from enclosures. The Federal Fisheries Law (SEMARNAP 1999) contains management rules for installing and operating fixed fishing gear. However, these rules are often ignored by cooperative groups which do not report catches from their stationary enclosures.

In the Carretas-Pereyra system, shrimp catch showed a declining trend for the period 2001-2006, which follows the trend in total catch. The relationship between catch and fishing effort shows a linear trend that fits Schaefer's (1954) model. Fishing mortality has been very high, so that the shrimp stock could have declined to very low levels affecting the population's capacity for recovery (Csirke 1989). On this scenario, the CPUE trend may be representing a collapsing fishery.

It is recognized that shrimp fisheries have high interannual variability in catch, and factors such as variations in fishing effort, environmental parameters, and a combination of both have been suggested (LópezMartínez et al. 2002) ${ }^{3}$. Inter-annual variations in total shrimp catch were significant in the Carretas-Pereyra system. These variations were attributed to shifts in effort, type of boat and fishermen skills. Moreover, shrimp productivity was influenced by climatic variables with cycles of different frequency (López-Martínez 2000). For instance, daily cycles mainly affect early-stage survival, seasonal cycles (e.g. salinity) may be determinant for shrimp distribution, or temperature can trigger reproductive season by catalyzing biochemical reactions.
Inter-annual cycles such as the El Niño phenomenon may affect survival and recruitment rates inducing long-term production fluctuations. These cycles cause periodical variations in CPUE depending on the resource exploitation level. A severe El Niño event was observed in 1982-1983, while a less intense but longer El Niño was recorded between 1991 and 1995 (Magaña et al. 2006). The El Niño event of 1998 has been the strongest ever recorded (Werner ${ }^{4}$ 2006). Sierra et al. (2001) considered that such a phenomenon favored shrimp recruitment and growth, and a high catch recovery recorded in 1999 in the Gulf of Tehuantepec supports this assumption. Afterwards, the lowest records of shrimp catch in history were observed, which agrees within the negative trend of this fishery (Fig. 6). According to Madrid et al. $(2001 \mathrm{a}, \mathrm{b})$ the colonization and extinction of shrimp populations are significantly related with the over fishing and the deterioration of the habitat. The Carretas-Pereyra system has been subjected to strong modifications of its natural conditions caused by the artificial opening of inlets, dredging and filling operations, and agriculture pesticides discharges. Indeed, these are some of the factors to be considered in the protection of the natural resources in the systems particularly, the fisheries.

Assuming that catch reflects population size, longterm population cycles can be detected with a noticeable occurrence (i.e. 1987-1989 and 1997-1999). If this is true, a new cycle would be expected to occur between 2007 and 2009 , and about every decade afterwards.

The models used in this study (Csirke 1989, Hilborn \& Walters 1992, Seijo et al. 2005) were applied in an attempt to conduct a comparative analysis of production and effort combining both observed values and official fishing statistic records. It is our contention that the results presented here indicate an underestimation of the calculated parameters, due to the insufficient capture records gathered from the stationary enclosures and furtive cast net activities. Nonetheless, the described production trends and the estimated MSY are still useful reference points to infer the current status of the CarretasPereyra shrimp fishery. In the case of cast nets, total catch fell below estimated MSY (248.4 metric tones $\mathrm{yr}^{-1}$ ) from 2000 to 2006, representing 58\% for that period. Yet, the observed effort (505 boats) surpassed $\mathrm{E}_{\mathrm{MSY}}$ by $45 \%$ (349

${ }^{3}$ López-Martínez J, S Hernández-Vázquez, F Arreguín-Sánchez, E Herrera-Valdivia, A García-Juárez, R Morales-Azpeitia \& M NevárezMartínez. 2002. Variabilidad interanual en la dinámica poblacional del camarón café Farfantepenaeus californiensis en el litoral de Sonora. Periodo 1978-2002. Foro de investigación de camarón del Pacífico: evaluación y manejo, 18 y 19 de junio, 2002. Instituto Nacional de la Pesca. CRIP-Mazatlán, Sinaloa, México, pp. 99-124.

${ }^{4}$ Werner S. 2006. El fenómeno ENOS.[on-line] <http://www.imn.ac.cr/educacion/enos.html> 
production units). MPY estimated in the Carretas-Pereyra system was greater than the catch recorded in 1983. Since then, and up until 2002, it remained below the recorded catch. Between 2003 and 2006, shrimp production seriously diminished reaching critical levels below those recorded in 1983. These results suggest a drastic decline of the inshore shrimp stock, which coincides with a previous study by Sierra et al. (2001) of white shrimp in the offshore waters of the Gulf of Tehuantepec.

Beyond the objective value of estimated MSY, it seems reasonable (within a conservative criterion to allow shrimp stock recovery) to recommend an annual total catch lower than that value. In fact, this type of model (production model) helps to calculate an optimum standardized fishing effort $\left(\mathrm{E}_{\mathrm{MSY}}\right)$ at equilibrium, more than a true MSY. Consequently, to promote the recovery of the resource, a 'precautory catch' (PC) derived from the effort produced by the fleet during the last years, may be calculated (Arena \& Rey 2003) following Gulland's (1969) approach, and taking into account half of the fishery life. For example, the average of the last seven years can be calculated according to the following equation:

$\mathrm{PC}=E_{M S Y} *[(C P U E 2000+C P U E 2001+\ldots \ldots . .+C P U E 2006) / 7]$

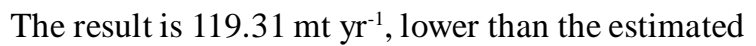
MSY. By a sustained application of PC, presumably the resource would experience a recovery process, and therefore its yield would gradually reach the point of CPUE $_{\mathrm{MSY}}$.

The fishing effort at which the difference between total income and costs of fishing is maximized $\left(\mathrm{E}_{\mathrm{MSE}}\right)$ was 225 boats, which in turn is much lower than both the observed effort (505 boats) and the estimated $\mathrm{E}_{\mathrm{MSY}}$ (349 boats). It becomes clear that effort at MEY will always be less than effort at MSY. A policy based on MSY will allow for maximum landings, revenue, and employment, but zero economic profits. Conversely, a policy based on MEY will maximize profits (i.e. attain economic efficiency), but at a lower level of landings, revenue, and employment. This assessment suggests an unprofitable fishery affected by shrimp overexploitation that provokes loss of fishing employment opportunities. In this scenario, government fishing subsidies may eventually contribute to maintain a constant effort in the Carretas-Pereyra system. These types of subsidies may temporarily help avoid economic collapse, but not necessarily the depletion of the shrimp stocks.

\section{Conclusion}

It is concluded that the shrimp fishery of the CarretasPereyra system has a common problem shared by most artisanal fisheries: deficiencies in record-keeping systems limit reliable evaluations of marine and freshwater resources. This fishery in practice has traditionally operated under an open-access regime. Catch from stationary enclosures represents a high proportion (38\%) of total catch, and its evaluation becomes imperative to propose sound management strategies of the shrimp stock. It is plausible that shrimp populations are influenced by long-term fluctuations, inter-annual variations, with cycles of 10 years which should be evaluated together with the shrimp abundance and the recruitment. The results of this study suggest a decline in both the CarretasPereyra system's shrimp stock and its level of profitability. Should this trend continues, it may cause an economic and biological collapse of this fishery in the near future. The analysis of CPUE and catch shows the need for a systematic monitoring of the fishery fluctuations. Future success of the Carretas-Pereyra shrimp fishery depends on biological and economic factors: biomass, environmental conditions, and reproductive productivity are basic components of this complex system, but annual shifts in effort, economic costs and benefits are also of crucial importance. A complete analysis of this fishery must include all these variables.

\section{Acknowledgments}

The first author acknowledges the fishermen's cooperative societies of La Encrucijada Biosphere Reserve and the staff of SAGARPA Subdelegación Federal de Pesca Chiapas, for the information provided. Comments and suggestions made by two anonymous reviewers greatly contributed to increase the quality of an earlier version of this manuscript.

\section{Literature cited}

Andrade GJ. 1992. Abundancia, disponibilidad y variación estacional de las postlarvas del camarón blanco (Penaeus schmitti) en Caño Sagua. Estado Zulia. Zootecnia Tropical 10(2): 117-130.

Arena G \& M Rey. 2003. Captura máxima sostenible de la corvina (Micropogonias furnieri) explotada en el río de la Plata y la zona común de pesca (período 1986-2002), 39 pp. Dirección Nacional de Recursos Acuáticos de Uruguay, Montevideo.

Cabrera-Jiménez J \& LA Soto. 2008. Fisheries and aquaculture implications of a meristic character in wild postlarvae of the shrimp, Litopenaeus vannamei (Boone, 1931) (Decapoda, Penaeoidea). Crustaceana 81(8): 993998. 
Csirke J. 1989. Introducción a la dinámica de poblaciones de peces. FAO Documento Técnico de Pesca 192: 1-82.

Day JW Jr, CAS Hall, WM Kemp \& A Yáñez-Arancibia. 1989. Estuarine ecology, 558 pp. John Wiley \& Sons, New York.

Edwards RRC. 1977. Field experiments on growth and mortality of Penaeus vannamei in a Mexico coastal lagoon complex. Estuarine and Coastal Marine Science 5: 107121.

Gamboa-Contreras JA \& M Tapia-García. 1998. Invertebrados bentónicos de la plataforma continental interna. In: Tapia-García M (ed). El Golfo de Tehuantepec: el ecosistema y sus recursos 9: 103-128. Universidad Autónoma Metropolitana Iztapalapa, México.

García S \& L Le Reste. 1981. Life cycles, dynamics, exploitation and management of coastal penaeids shrimp stocks. FAO Fisheries Technical Paper 203: 1-215.

García-Borbón JA, J Madrid-Vera, S Ramos-Cruz, AR García-Juárez, D Chávez-Herrera, D Castro-Castro, E Zárate-Becerra, LF Beléndez-Moreno, E MoralesBojórquez, P Loreto-Campos, S Hernández, A RamosMontiel, M Anguiano-Carrazco \& C Alvarado-Sarabia. 2004. Inicio de la temporada de veda 2004 para la pesquería de camarón del océano Pacífico mexicano. Informe de Investigación, Dirección General de Investigación Pesquera en el Pacífico Norte, 33 pp. Instituto Nacional de la Pesca, SAGARPA, Mazatlán.

González-Becerril A, E Espino-Barr, M Cruz-Romero \& A Ruiz-Luna. 2000. Determinación de la unidad de esfuerzo de pesca en una pesquería artesanal ribereña en Manzanillo, Colima, México. Ciencias Marinas 26(1): 113-124.

Grinstead Ch \& JL Snell. 1997. Introduction to probability, 510 pp. American Mathematical Society, Rhode Island.

Guerra SA \& JL Sánchez. 1998. Fundamentos de explotación de recursos vivos marinos, 249 pp. Acribia, Zaragoza.

Gulland JA. 1969. Manual of methods for fish stock assessment. Part. 1. Fish population analysis. FAO Manual of Fisheries Science 4: 1-154.

Hendrickx ME. 1995. Camarones. In: Fischer W, F Krupp, W Scheider, C Sommer, KE Carpenter \& VH Niem (eds). Guía FAO para la identificación de especies para los fines de pesca. Pacífico centro-oriental. Vol. I. Plantas e invertebrados, pp. 417-537. FAO, Roma.

Hilborn R \& CJ Walters. 1992. Quantitative fisheries stock assessment. Choice, dynamics and uncertainty, 570 pp. Chapman \& Hall, New York.

López-Martínez J. 2000. Dinámica de la pesquería del camarón (Penaeus californiensis) en el litoral sonorense, y su relación con algunos parámetros océano-atmosféricos. Tesis de doctorado, Centro Interdisciplinario de Ciencias Marinas, La Paz, 174 pp.
Madrid VJ, D Chávez-Herrera \& JM Melchor-Aragón. 2001a. Sobre la abundancia de camarón azul (Litopenaeus stylirostris) en la plataforma continental de Sinaloa y el norte de Nayarit, México durante los junios, julios y agostos de 1992-2001. Informe de Investigación, Instituto Nacional de la Pesca, 40 pp. CRIP-Mazatlán, Sinaloa.

Madrid VJ, D Chávez-Herrera \& JM Melchor-Aragón. 2001b. Situación actual de las poblaciones de camarón café (Farfantepenaeus californiensis), en las costas de Sinaloa y norte de Nayarit, México. Informe de Investigación. Instituto Nacional de la Pesca, 33 pp. CRIP-Mazatlán, Sinaloa.

Menz A. 1976. Bioeconomics of penaeid shrimps in a lagoon complex on the Mexican Pacific coast. Ph. D. Dissertation, Graduate School, University of Liverpool, Liverpool, 145 pp.

Morales-Bojórquez E, J López-Martínez \& S HernándezVázquez. 2001. Dynamic catch-effort model for brown shrimp Farfantepenaeus californiensis (Holmes) from the Gulf of California, Mexico. Ciencias Marinas 27(1): 105124.

Parra URE. 1992. Resultados preliminares sobre los requerimientos proteicos de juveniles de camarón blanco (Penaeus schmitti, Burkenroad) en acuarios experimentales. Zootecnia Tropical 10(2): 189-203.

Pauly D. 1983. Algunos métodos simples para la evaluación de recursos pesqueros tropicales. FAO Fisheries Technical Paper 234: 1-49.

Rivera-Velázquez G, LA Soto, IH Salgado-Ugarte \& EJ Naranjo. 2008. Growth, mortality and migratory pattern of white shrimp (Litopenaeus vannamei; Crustacea, Penaeidae) in the Carretas-Pereyra coastal lagoon system, southern Mexico. Revista de Biología Tropical 56(2): 523533.

Seijo JC, O Defeo \& S Salas. 1997. Bioeconomía pesquera. Teoría, modelación y manejo. FAO Documento Técnico de Pesca 368: 1-176.

SEMARNAP. 1999. Ley de pesca y su reglamento, $113 \mathrm{pp}$. Secretaria de Medio Ambiente Recursos Naturales y Pesca, México.

Sierra P, C Acosta, JA García, AR García, A Liedo, JM Melchor, S Ramos, A Rosas, MP Toledo \& E Zárate. 2001. Camarón del Océano Pacífico. In: SAGARPA (ed). Sustentabilidad y pesca responsable en México. Evaluación y manejo. 1999-2000, pp. 5-50. Instituto Nacional de la Pesca, SAGARPA, México.

Sparre P \& SC Venema. 1997. Introducción a la evaluación de recursos pesqueros tropicales. Parte 1: Manual. FAO Documento Técnico de Pesca 306/1: 1-696.

Toledo A. 1994. Riqueza y pobreza en el Estado de Oaxaca y Chiapas, 50 pp. Centro de Ecología y Desarrollo, México.

Recibido el 11 de febrero de 2009 y aceptado el 4 de septiembre de 2009 